\title{
ENZYMATIC AND CATALYSTIC ENCHANCEMENT OF METHANE PRODUCTION FROM CORN SILAGE AND GRAIN RESIDUES
}

\author{
Vilis Dubrovskis, Imants Plume \\ Latvia University of Agriculture \\ vilisd@inbox.lv, imants.plume@inbox.lv
}

\begin{abstract}
Many biogas plants used corn silage and grain processing (dryers) residues as a raw material. Hydraulic retention time working with such raw materials is relatively long and requires large volumes of bioreactors. Variety of additives can be used to improve the anaerobic digestion process. This article shows the results of the study where the enzyme mixture and catalyst Metaferm are used for the digestion process echancement. Corn silage and grain processing residues were digested in 0.721 bioreactors at temperature $38{ }^{\circ} \mathrm{C}$ in the batch mode process. 2 biorectors were for control purposes and contained inoculums only. The other 14 biorectors contain biomass substrates without/with added enzyme mixture or catalyst Metaferm. Addition of enzyme mixture $(0.5 \mathrm{~g})$ in bioreactors with corn silage or grain processing residues increases the average methane yield by $7.76 \%$ or $4.48 \%$ respectively. Addition of catalyst Metaferm $(1 \mathrm{ml})$ into bioreactors with corn silage or grain processing residues increases the average methane yield by $1.79 \%$ or $6.72 \%$ respectively.
\end{abstract}

Keywords: anaerobic digestion, methane, enzymes, corn silage, grain processing residues.

\section{Introduction}

The need to develop and improve sustainable energy resources is considerable due to the finite nature of our fossil fuels. Recent modification of laws, development of technologies and business movement have encouraged the transition to a recycling-based society. Today's economy and technologies largely depend upon energy resources that are renewable as well as eco-friendly. Biogas is an environment friendly, economic and alternative mean to substitute the fossil fuel. Bacteria and enzymes play the leading role in anaerobic digestion (AD) and they are essential for efficient process [1-3].

Commonly used substrates for biogas production include industrial waste, agricultural wastes, dairy and pig-breeding waste, e.g., fodder residues and manure, and energy crops, e.g., corn and grasses. However, some substrates can be degraded (so biogas is produced) very slowly because: the molecular structure of biomass is poorly accessible to microorganisms and their enzymes (for instance, because of their highly crystalline structure or due to the small surface area available). In substrates for biogas production, the main sources of methane are sugars and other small molecules. In the plant (lignocellulosic) substrates such mall molecules come from the breakdown of starch, cellulose and hemicellulose. While starch ( $\alpha-1-4$ linked D-glucose) is relatively easy and quick to break down biologically, cellulose ( $\beta$-1-4 linked D-glucose) and hemicellulose (a polymer of various sugars and uronic acids) retaining the structure of the plant, are characterized as difficult and slowly degradable biomass. The breakdown of cellulose and hemicellulose is further complicated by the bonds between different cellulose chains and by the presence of lignin, another polymer, which slows down the breakdown process. It is generally believed that lignin cannot be degraded by anaerobic bacteria, although this has been challenged [4] and may even inhibit the degradation of other substances like cellulose. Pectin also affects breakdown, binding cellulose fibrils together and binding plant cells together [5]. Breaking down this lignocellulose complex is very important for biogas production [6]. A number of authors [4; 7; 8] have reported significant improvement in biogas production when crude and commercial enzymes are used in the pre-treatment of complex organic matter.

There have been studies on the improvement of biogas production from lignocellulolytic materials, one of the largest and renewable sources of energy on the earth, after pre-treatment with cellulases and cellulase-producing microorganisms [4]. Enzymes that break down biomass are already present in anaerobic digesters as they are produced by the microorganisms of anaerobic digestion. To enhance this breakdown, a mixture of enzymes can be added and may include cellulose-, hemicellulose-, pectin- and starch-degrading enzymes.

The addition of enzymes into substrates for anaerobic digestion has been evaluated in many different studies. There is some evidence to suggest that enzymes added directly to the biogas reactors have no significant effect [9] and are degraded quickly after addition [10]. Several batch anaerobic 
digestion studies have indicated that the addition of enzymes to the first stage of a two-stage anaerobic digestion process leads to slightly higher substrate solubilisation (leading to higher biogas yield), such as with addition of cellulases on grass [11] or with cellulosic enzyme cocktail on wheat straw [12].

Some studies showed that enzymatic pre-treatment in a dedicated vessel leads to higher substrate solubilisation or biogas yields in batch AD tests, for example, with pectinase on hemp [13] or various agricultural residues with a cellulolytic enzyme cocktail $[14 ; 15]$ The effects of the addition of enzyme products containing cellulase, hemicellulase, and $\beta$-glucosidase to anaerobic digestion systems were studied using JoseTall Wheat Grass (wheat grass) as a model substrate. Anaerobic digestion tests were performed using batch reactors operated at $50^{\circ} \mathrm{C}$. The enzyme products showed positive effects on the solubilization of wheat grass when used alone to treat wheat grass. However, there were not found significant differences in biogas and methane yields and volatile solids reduction when the enzyme products were tested in the $\mathrm{AD}$ systems. This reveals that the microorganisms present in the inoculum were effective in carrying out the digestion of wheat grass [11].

Small increases in biogas yield were seen with continuous anaerobic digestion of different agricultural residues pre-treated in a dedicated vessel [16]. A study by a Swiss [17] group looked at the effect of 25 different commercially available enzyme preparations including enzyme mixtures marketed to biogas plants as well as pure enzymes normally marketed to other industries. They found that the effect of enzymatic pre-treatment on biogas yield from sludge and manure was minimal and speculated that this was because the enzymes were being degraded by the native microorganisms. Some of the enzyme products increased the biogas yield by around $10 \%$ in grass silage and green waste silage in batch tests. These enzymes also increased the methane concentration in the gas produced in the first week. However, the authors note that the enzyme dosage was so high that it is unlikely to be economically feasible.

The aim of this study was to evaluate the biogas and methane production from corn silage and grain residues, to justify whether the addition of biocatalyst Metaferm and enzyme mixtures into substrates can cause any positive effect.

\section{Materials and methods}

Before fermentation, the raw material (corn silage and grain residues) samples were analysed for dry matter and organic matter content. The data were used for calculation of organic load rates.

Enzyme FM is the mixture of enzymes cellulase, b- glikonase and xilanase, containing essential elements for the anaerobic fermentation process advancement. Metaferm is an innovative catalyst for enhancement of the AD process. Metaferm contains multiple ferments, micronutrients, and B-group vitamins. The true composition of enzyme mixture or biocatalyst Metaferm is not known due to the proprietary rights of the producing company.

The widely applied methods were used for the AD process investigation [9] in 16 experimental bioreactors with volume of 0.72 litres. 2 bioreactors for control were filled with $500.0 \pm 0.2 \mathrm{~g}$ inoculums and the rest bioreactors were filled with mixtures of inoculums $(500 \mathrm{~g})$, added biomass $(15 \pm 0.005 \mathrm{~g})$, enzyme mixture FM or catalyst Metaferm, according to the experimental plan, see Table 1.

Dry organic matter (DOM) content was determined by weighting of the initial biomass samples, dried in the thermostat at $105^{\circ} \mathrm{C}$ and placed for ashing in the oven ("Nabertherm" type) at $550{ }^{\circ} \mathrm{C}$. All the components were carefully mixed together and filled in the bioreactors. All bioreactors were placed into the heated thermostat at the same time before starting of anaerobic digestion. Gas released from each bioreactor was collected in a storage bag positioned outside the container. Gas volumes were measured using the flow meter (Ritter drum-type gas meter). The composition of gases, including oxygen, carbon dioxide, methane, and hydrogen sulphide was measured by help of the gas analyser (model GA 2000). The substrate $\mathrm{pH}$ value was measured before and after finishing the AD process, using a $\mathrm{pH}$ meter (model PP-50) with accessories. Scales (Kern, model KFB 16KO2) was used for weighting of the total weight of substrates before and after the AD process.

Fermented cattle manure (from 1201 bioreactor working in continuous mode) was used as the inoculum. The batch mode $\mathrm{AD}$ process was ongoing at temperature $38 \pm 0.5^{\circ} \mathrm{C}$. Biogas released was collected in gas bags for further measurements of the gas volume and elemental composition. Biogas 
and methane volumes and the gas composition were measured during the $\mathrm{AD}$ process at regular time intervals. The AD process was provided until biogas emission ceases. The obtained experimental data were processed using appropriate statistical methods.

\section{Results and discussion}

The results of investigation of sample substrates, including inoculums, corn silage and grain residues with and without enzyme mixture and Metaferm, before starting the AD process, are shown in Table 1.

Table 1

Results of analyses of raw material samples before anaerobic digestion

\begin{tabular}{|c|c|c|c|c|c|c|c|c|}
\hline $\begin{array}{c}\text { Bio- } \\
\text { reactors }\end{array}$ & Raw material & $\mathbf{p H}$ & $\begin{array}{c}\text { TS, } \\
\mathbf{\%}\end{array}$ & $\begin{array}{c}\text { TS, } \\
\mathbf{g}\end{array}$ & $\begin{array}{c}\text { ASH, } \\
\mathbf{\%}\end{array}$ & $\begin{array}{c}\text { DOM, } \\
\mathbf{\%}\end{array}$ & $\begin{array}{c}\text { DOM, } \\
\mathbf{g}\end{array}$ & $\begin{array}{c}\text { Weight, } \\
\mathbf{g}\end{array}$ \\
\hline \multirow{2}{*}{ R1; R16 } & $\mathrm{IN}$ & 7.4 & 1.43 & 7.15 & 20.15 & 79.85 & 5.71 & 500 \\
\cline { 2 - 9 } & $\mathrm{CS}$ & 4.28 & 23.19 & 3.164 & 9.06 & 90.94 & 2.877 & 15 \\
\hline \multirow{2}{*}{ R2-R3 } & $\mathrm{IN+CS}$ & 7.25 & 2.00 & 10.314 & 16.74 & 83.26 & 8.587 & 515 \\
\cline { 2 - 9 } & $\mathrm{FM}$ & 7.51 & 89.83 & 0.449 & 9.04 & 90.96 & 0.408 & 0.5 \\
\hline R4-R6 & IN+CS+FM & 7.30 & 2.01 & 10.763 & 16.43 & 83.57 & 8.995 & 515.5 \\
\hline \multirow{2}{*}{ R7-R8 } & IN+CS+1 ml MF & 7.38 & 2.00 & 10.314 & 16.74 & 83.26 & 8.587 & 516 \\
\cline { 2 - 8 } & GR & - & 47.1 & 7.065 & 9.74 & 90.26 & 6.377 & 15 \\
\hline R9-R10 & IN+GR & 7.42 & 2.76 & 14.215 & 14.97 & 85.03 & 12.087 & 515 \\
\hline R11-R13 & IN+GR+0,5 FM & 7.43 & 2.85 & 14.664 & 14.79 & 85.21 & 12.495 & 515.5 \\
\hline R14-R15 & IN+GR+1 ml MF & 7.44 & 2.76 & 14.215 & 14.97 & 85.03 & 12.087 & 516 \\
\hline
\end{tabular}

Note: IN - inoculum; CS - corn silage; FM - enzyme mixture; GR - grain residues; ASH - ashes;

$T S$ - total solids; DOM - dry organic matter (on raw substrate basis); RI-R16 - bioreactors.

The digestate (finished cow manure) with very low organic matter content serves as an inoculum for providing of the $\mathrm{AD}$ process. Generally the $\mathrm{AD}$ process ceases in such inoculums alone, but there are still enough numbers of live bacteria to provide rapid degradation of the new portion of the organic matter included in substrate at the start of the AD process. Composition of corn silage (CS) used in this study was not the most successful choice as the dry matter content was less than optimal. The grain residue (GR) composition from various biogas plants tends to be very different. In this study the grain residue biomass has relatively high humidity $(52.9 \%)$ that can be explained by the fact that the sample was taken from real biogas producing plant just before GR filling into the digester and GR were partly saturated with silage effluent or liquid fraction of digestate. Such the moistening procedure of grain residues in a real biogas plant is provided in order to obtain partly saturated GR reducing the chaff rise towards the upper layer of the bioreactor.

The biogas and methane yields from bioreactors R2-R15 with added biomass are shown in Table 2 and Fig. 2 with already subtracted average values of biogas and methane obtained from control reactors R1 and R16 filled with pure inoculum.

The production of biogas and methane from corn silage and grain residues with and without enzyme mixtures and Metaferm from control reactors is presented in Table 2.

Table 2

Production of biogas and methane

\begin{tabular}{|c|c|c|c|c|c|}
\hline Bioreactor/Raw material & $\begin{array}{c}\text { Biogas, } \\
\mathbf{l}\end{array}$ & $\begin{array}{c}\text { Biogas, } \\
\mathbf{l ~ g}^{-1} \text { DoM }\end{array}$ & $\begin{array}{c}\text { Methane, } \\
\text { aver. } \%\end{array}$ & $\begin{array}{c}\text { Methane, } \\
\mathbf{l}\end{array}$ & $\begin{array}{c}\text { Methane, } \\
\mathbf{l ~ g}_{\text {DoM }}^{-1}\end{array}$ \\
\hline R2 500 g IN+15 g CS & 2.301 & 0.727 & 52.1 & 1.199 & 0.379 \\
\hline R3 500 g IN+15 g CS & 1.700 & 0.537 & 54.8 & 0.921 & 0.291 \\
\hline Average: 500 g IN+15 g CS & $\mathbf{2 . 0 \pm 0 . 3}$ & $\mathbf{0 . 6 3 2} \pm \mathbf{0 . 0 9}$ & $\mathbf{5 3 . 1 5} \pm \mathbf{1 . 0 3}$ & $\mathbf{1 . 0 6} \pm \mathbf{0 . 1 4}$ & $\mathbf{0 . 3 3 5} \pm \mathbf{0 . 0 4}$ \\
\hline R4 500 g IN+15 g CS+0.5 FM & 2.715 & 0.755 & 52.6 & 1.416 & 0.396 \\
\hline R5 500 g IN+15 g CS+0.5 FM & 2.325 & 0.643 & 54.6 & 1.27 & 0.356 \\
\hline R6 500 g IN+15 g CS+0.5 FM & 2.307 & 0.643 & 53.9 & 1.244 & 0.348 \\
\hline Average: IN+CS+FM & $\mathbf{2 . 4 \pm 0 . 2 5}$ & $\mathbf{0 . 6 8 1} \pm \mathbf{0 . 0 8}$ & $\mathbf{5 3 . 5 7 \pm 1 . 4 3}$ & $\mathbf{1 . 3 1 \pm 0 . 1 1}$ & $\mathbf{0 . 3 6 1} \pm \mathbf{0 . 0 4}$ \\
\hline
\end{tabular}


Table 2 (continued)

\begin{tabular}{|c|c|c|c|c|c|}
\hline Bioreactor/Raw material & $\begin{array}{c}\text { Biogas, } \\
\text { I }\end{array}$ & $\begin{array}{l}\text { Biogas, } \\
l^{\cdot} \mathrm{g}^{-1} \text { DOM }\end{array}$ & $\begin{array}{c}\text { Methane, } \\
\text { aver. \% }\end{array}$ & $\begin{array}{c}\text { Methane, } \\
\text { I }\end{array}$ & $\begin{array}{c}\text { Methane, } \\
l \cdot g^{-1} \text { DOM }\end{array}$ \\
\hline R7 500 g IN+15 g CS+1 ml MF & 1.700 & 0.537 & 54.8 & 0.932 & 0.294 \\
\hline R8 500 g IN+15 g CS+1 ml MF & 2.199 & 0.695 & 55.8 & 1.226 & 0.387 \\
\hline Average: $\mathrm{IN}+\mathrm{CS}+\mathrm{MF}$ & $1.95 \pm 0.25$ & $0.616 \pm 0.08$ & $55.29 \pm 0.46$ & $1.08 \pm 0.15$ & $0.341 \pm 0.05$ \\
\hline R9 500 g IN+15 g GR & 3.700 & 0.580 & 51.7 & 1.911 & 0.300 \\
\hline R10 500 g IN+15 g GR & 2.899 & 0.454 & 52.1 & 1.510 & 0.237 \\
\hline Average: IN+GR & $3.3 \pm 0.4$ & $0.517 \pm 0.06$ & $51.87 \pm 0.22$ & $1.711 \pm 0.2$ & $0.268 \pm 0.03$ \\
\hline R11 500 g IN+15 g GR+0.5 FM & 3.700 & 0.580 & 51.8 & 1.918 & 0.282 \\
\hline R12 500 g IN+15 g GR+0.5 FM & 3.601 & 0.565 & 52.6 & 1.895 & 0.279 \\
\hline R13 500 g IN+15 g GR+0.5 FM & 3.600 & 0.565 & 52.5 & 1.888 & 0.278 \\
\hline Average: $\mathrm{IN}+\mathrm{GR}+\mathrm{FM}$ & $3.63 \pm 0.07$ & $0.570 \pm 0.01$ & $52.31 \pm 0.47$ & $1.90 \pm 0.02$ & $0.280 \pm 0.01$ \\
\hline R14 500 g IN+15 g GR+1 ml MF & 3.600 & 0.565 & 54.9 & 1.978 & 0.310 \\
\hline R15 $500 \mathrm{~g} \mathrm{IN+15} \mathrm{g} \mathrm{GR+1} \mathrm{ml} \mathrm{MF}$ & 3.100 & 0.486 & 53.9 & 1.670 & 0.262 \\
\hline Average: $\mathrm{IN}+\mathrm{GR}+\mathrm{MF}$ & $3.35 \pm 0.25$ & $0.526 \pm 0.04$ & $54.41 \pm 0.53$ & $1.82 \pm 0.15$ & $0.286 \pm 0.02$ \\
\hline R16 IN $500 \mathrm{~g}$ & 0.1 & - & - & 0.002 & - \\
\hline R1 IN $500 \mathrm{~g}$ & 0.0 & - & - & 0.0 & - \\
\hline
\end{tabular}

Note: $l \cdot g^{-1}$ Dом-litres per $1 \mathrm{~g}$ dry organic matter added (added fresh biomass into inoculums).

Average methane content in biogas for corn silage and grain residue samples with and without enzyme mixture and catalyst Metaferm is shown in Fig. 1.

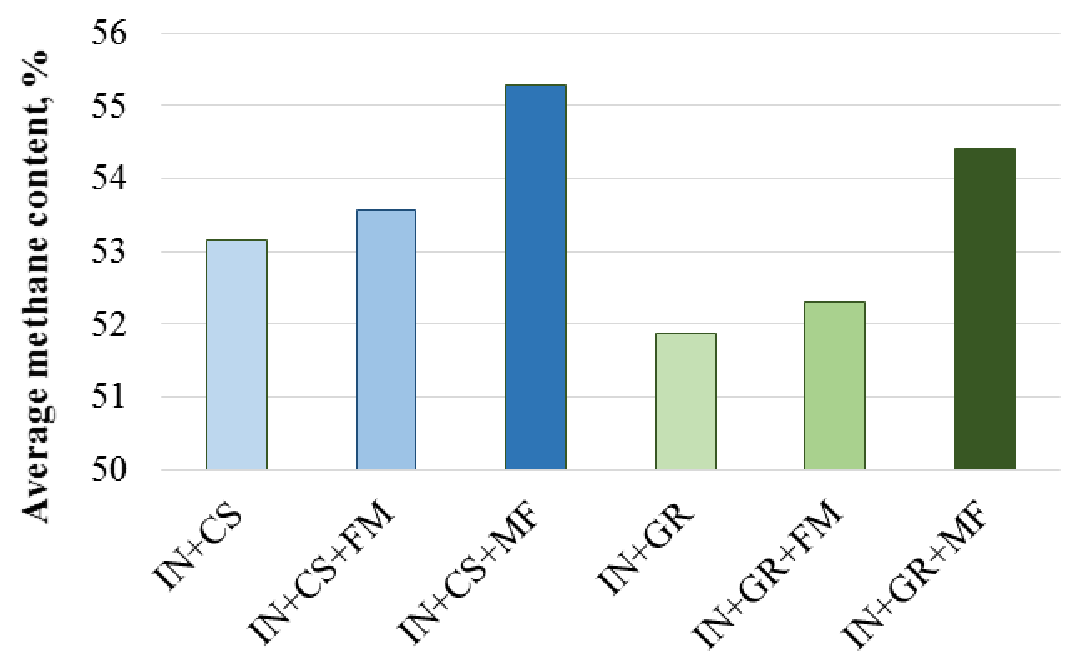

\section{Substrates in bioreactors}

Fig. 1. Average methane content in biogas without and with added enzyme mixture and

Metaferm: CS - corn silage; GR- grain residues; FM - mixture of enzymes; MF- Metaferm

The methane content in biogas obtained from all bioreactors with added enzyme mixture or Metaferm was higher compared to the bioreactors without them (Fig. 1). Higher methane content can be explained by the fact that both enzyme mixture and Metaferm improve bioconversion of raw materials. Surprisingly that higher increase of methane content was obtained from substrates with Metaferm addition compared to the methane content increase obtained from the samples with enzyme mixture addition. Increasing the methane content in biogas can lower carbon dioxide emissions and improve the efficiency of cogeneration engines.

Specific average biogas and methane production yields $\left(1 \cdot \mathrm{g}^{-1} \mathrm{DOM}\right)$ calculated for bioreactors without and with added enzyme mixture or Metaferm into corn silage and grain residue biomass are shown in Fig. 2. 


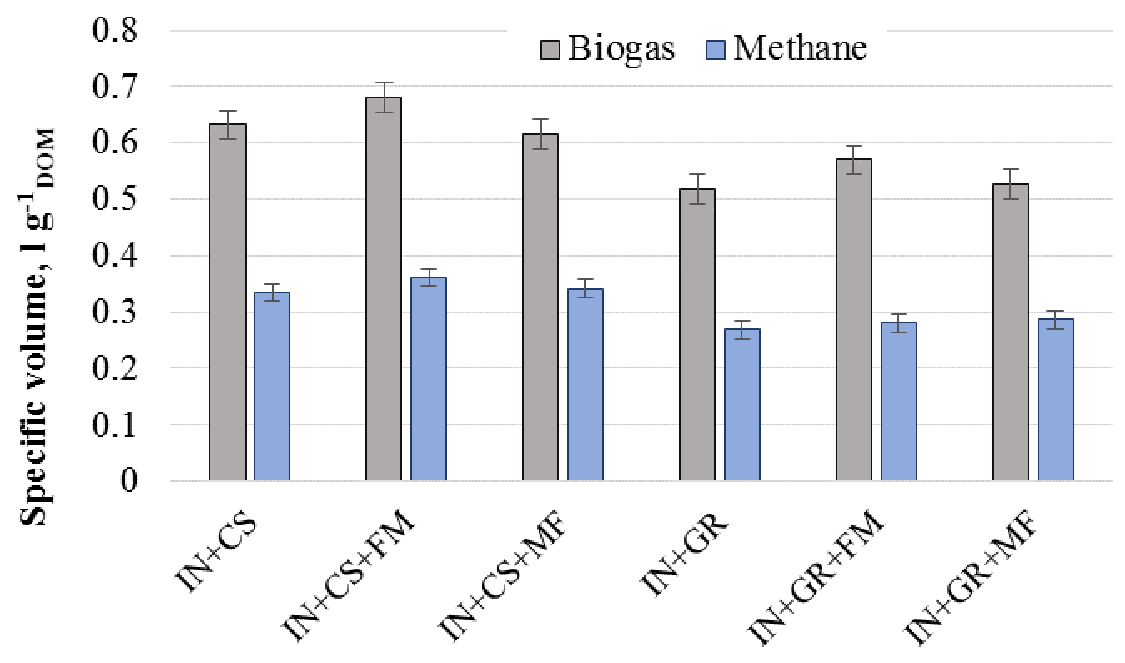

Substrates in bioreactors

Fig. 2. Specific average biogas and methane yields from corn silage and grain residue samples without and with added FM and MF: CS - corn silage; FM - mixture of enzymes; MF- Metaferm

There are shown (Table 2 and Fig. 2) the average data calculated for all bioreactors containing corn silage biomass. The specific methane yield was higher $(7.76 \%)$ from the samples provided with mixture of enzymes, and only slightly higher $(1.79 \%)$ from the samples with $1 \mathrm{ml}$ Metaferm. The specific methane yield was higher $(4.48 \%)$ from the samples provided with mixture of enzymes and higher $(6.72 \%)$ from the samples with $1 \mathrm{ml}$ Metaferm. Comparison of the obtained results with other researcher's data would not be correct, as the additive used in this study has original composition composed for specific corn silage and grain residue biomass in Latvia and was utilized for the first time for the given biomass.

\section{Conclusions}

1. Average specific methane yield from bioreactors with corn silage with enzyme mixtures $(0.5 \mathrm{~g})$ was $0.361 \pm 0.04 \mathrm{l} \cdot \mathrm{g}^{-1}$ DOM or by $7.76 \%$ higher compared to that obtained from corn silage without added enzymes.

2. Average specific methane yield from bioreactors with corn silage with catalyst Metaferm (1 ml) was $0.3415 \pm 0.04 \mathrm{l} \cdot \mathrm{g}^{-1}$ DOM or by $1.79 \%$ higher compared to the specific methane volume obtained from corn silage without added Metaferm.

3. Average specific methane yield obtained from bioreactors with grain residues with enzyme mixture $(0.5 \mathrm{~g})$ was $0.280 \pm 0.01 \mathrm{l} \cdot \mathrm{g}^{-1}$ DOM or by $4.48 \%$ higher compared to that obtained from grain residues without added enzymes.

4. Specific methane yields from bioreactors with grain residues with Metaferm $(1 \mathrm{ml})$ was $0.286 \pm 0.02 \mathrm{l} \cdot \mathrm{g}^{-1}$ DOM or by $6.72 \%$ higher compared to that obtained from grain residues without added Metaferm.

5. Average methane content in biogas increases by $0.70 \%$ or $0.84 \%$ if enzyme mixture was added to corn silage or to grain residues, respectively.

6. Average methane content in biogas increases by $0.84 \%$ or $0.9 \%$, if enzyme mixture was added to grain residues.

7. The investigated increase of the average specific methane yield or methane content caused by addition of enzyme mixture or catalyst Metaferm to corn silage or to grain residues is relatively low, and further investigations should be performed for every case, based on the individual substrate, anaerobic process conditions and desired criteria of effectiveness.

\section{Acknowledgement}

This investigation was supported by the Latvian National Research Programme LATENERGI. 


\section{References}

1. Mudhoo A. Biogas Production: Pretreatment Methods in Anaerobic Digestion. Wiley, 2012, $352 \mathrm{p}$.

2. Kaltschmitt M. Methodenhandbuch, 2010, Leipzig, 93 p.

3. Dubrovskis V., Adamovičs A. Bioenerǵêtikas horizonti (Horizons of bioenergetics), Jelgava: Latvia University of Agriculture, 2012. 352 p. (In Latvian).

4. Parawira W. Enzyme research and applications in biotechnological intensification of biogas production. Critical reviews in biotechnology, vol. 32, 2012, pp. 172-186.

5. Carpita N.C., Gibeaut D.M. Structural models of primary cell walls in flowering plants: consistency of molecular structure with the physical properties of the walls during growth. The Plant Journal, vol, 3, 1993. pp. 1-30.

6. Noike T., Endo G., Chang J., Yaguchi J., Matsumoto J. Characteristics of carbohydrate degradation and the rate limiting step in anaerobic digestion. Biotechnology and Bioengineering 27, 1985, pp. 1482-1489.

7. Kreuger, E., Nges, I.A., Björnsson, L., 2011. Ensiling of crops for biogas production: effects on methane yield and total solids determination. Biotechnology for Biofuels 4, p44.

8. Vervaeren H., Hostyn K., Ghekiere G., Willems B. Biological ensilage additives as pretreatment for maize to increase the biogas production. Renewable Energy, vol. 35, 2010, pp. 2089-2093.

9. Rintala J.A., Ahring B.K. Thermophilic anaerobic digestion of source-sorted household solid waste: the effects of enzyme additions. Applied Microbiology and Biotechnology 40, 1994, pp. 916-919.

10. Binner R., Menat V., Huber H. etc., Reuter M. Comparative study of stability and half-life of enzymes and enzyme aggregates implemented in anaerobic biogas processes. Biomass conversion and biorefinery, vol 1, 2011, pp. 1-8.

11. Romano R.T., Zhang R., Teter S. etc. 2009. The effect of enzyme addition on anaerobic digestion of Jose Tall Wheat Grass. Bioresource Technology 100, pp4564-4571.

12. Quéméneur M., Bittel M., Trably E. etc. Effect ofenzyme addition on fermentative hydrogen production from wheat straw. International Journal of Hydrogen Energy, vol. 37, 2012. pp. 10639-10647.

13. Pakarinen A., Maijala P., Jaakkola S. etc. Evaluation of preservation methods for improving biogas production and enzymatic conversion yields of annual crops. Biotechnol Biofuels, vol 4, 2011, p. 20.

14. Pakarinen A., Zhang J., Brock T. etc. Enzymatic accessibility of fiber hemp is enhanced by enzymatic or chemical removal of pectin. Bioresource Technology, vol. 107, 2012, pp. 275-281.

15. Suárez Q.T., Plöchl M., Budde J. etc. Enhanced methane formation through application of enzymes: Results from continuous digestion tests. Energy Fuels, vol. 25, 2011, pp. 5378-5386.

16. Suárez Q.T., Plöchl M., Budde J. etc. Results of batch anaerobic digestion test - effect of enzyme addition. Agricultural Engineering International: CIGR Journal, vol. 14, 2012, pp. 38-50.

17. Warthmann R., Baum S., Baier U. Massnahmen zur Optimierung der Vergärung durch Vorbehandlung, Prozess- und Verfahrenstechnol und Hilfsstoffe (Measures for optimizing the fermentation by pretreatment, process and process engineering and auxiliary materials), Bundesamt für Energie BFE, Switzerland, 2012, Project No. 103312 / 154366). (In German). 